\title{
Temporal Lobectomy: Review of 100 Cases with Major Hippocampectomy
}

\author{
Theodore Rasmussen and William Feindel
}

\begin{abstract}
One hundred consecutive patients between 1961 and 1980, with temporal lobectomy including excision of half or more of the hippocampal formation, have been analyzed for degree of reduction of seizures. Thirty-nine percent have become and remained seizure free for follow-up period of 2 to 24 years (median 12 years). Another 24 patients achieved a marked reduction in seizure tendency as defined in the report and 25 showed a lesser degree of improvement. In fifteen patients no change in seizure frequency was recorded. Thus in this series of 100 patients, a complete or marked reduction of the seizure tendency was achieved in $63 \%$.
\end{abstract}

RÉSUMÉ: Lobectomie temporale: revue de 100 cas avec hippocampectomie majeure. Nous avons analysé, en regard du degré de réduction des crises épileptiques, 100 cas consécutifs de patients ayant subi une lobectomie temporale comprenant une excision d'au moins la moitié de l'hippocampe, entre 1961 et 1980 . Chez $39 \%$ des patients, les crises épileptiques ont cessé et n'ont pas récidivé après une période de suivi de 2 à 24 ans (médiane de 12 ans). Chez 24 autres patients la tendance aux crises a diminué de façon marquée, tel que décrit dans le présent article, et 25 patients ont noté un moindre degré d'amélioration. Quinze patients n'ont pas présenté de changements dans la fréquence de leurs crises. Donc, dans cette série de 100 patients, une réduction marquée ou complète de la tendance aux crises a été atteinte dans $63 \%$ des cas.

Can. J. Neurol. Sci. 1991; 18: 601-602

In 1982 a review of some localizational aspects of temporal lobe epilepsy was presented, based upon a review of 101 patients of the Montreal Neurological Institute (MNI) surgical seizure series who had been seizure free for a minimum period of 5 years after temporal lobectomy. ${ }^{1}$ In these patients, whose follow-up periods ranged up to 23 years (median duration 12 years), one could be reasonably certain that all essential epileptogenic mechanisms were contained in the excised brain tissues. In 30 of these 101 patients, in addition to the removal of the temporal convexity and amygdala, the removal included the pes and most of the body of the hippocampus (Figure 1). In 13 patients the medial temporal removal was limited to the amygdala or the amygdala plus the anterior part of the pes. In the remaining 58 patients a more extensive but partial removal of the hippocampus had been carried out. With the additional clinical material now available a closer look at the results and repercussions of removal of medial temporal structures, in particular the hippocampus, seem indicated.

\section{MeThod}

A retrospective review was made of temporal lobectomy patients operated on by our two neurosurgical services (TR and WF). To avoid overlap, patients operated upon by Dr. Andre Olivier and other members of the neurosurgical staff were excluded. Also excluded were patients with less than 2 years follow-up and those in whom any extra-temporal cortical excisions had been carried out in addition to the temporal lobectomy. All patients had part or most of the amygdaloid nucleus removed. The surgeons operative drawings and the detailed operation reports were used to divide the patients into three groups on the basis of the extent of the hippocampal removal. The 3 groups identified were (1) those patients with maximal hippocampal removal (removal of the pes plus half or more of the body), (2) a second group with minimal hippocampal removal (no hippocampal removal at all, or removal of less than the anterior half of the pes), and (3) an intermediate group, in whom the whole pes plus the anterior few millimeters of the body of the hippocampus was excised.

Starting with the operations carried out in 1980 and going backward year by year to 1961,100 consecutive cases, as described above, were collected for groups 1 and 2 for analysis and presentation to this symposium. Over this period of time another 183 patients had accumulated in the third group with an intermediate extent of hippocampal excision. The data on this group will not be presented in detail at this time.

This report focuses upon the results achieved in reducing the seizure tendency in the first group, those temporal lobectomy patients in whom the medial removal included the amygdala, the pes and half or more of the body of the hippocampus. The following report will focus on the results achieved in the second group, those with no, or minimal hippocampal excision. ${ }^{2}$

From the Montreal Neurology Institute and Hospital, Department of Neurology and Neurosurgery, McGill University, Montreal

Reprint requests to: T. Rasmussen, M.D., 3801 University Street, Montreal, Quebec, Canada H3A 2B4 


\section{Patients Seizure Free Post Temporal Lobectomy}

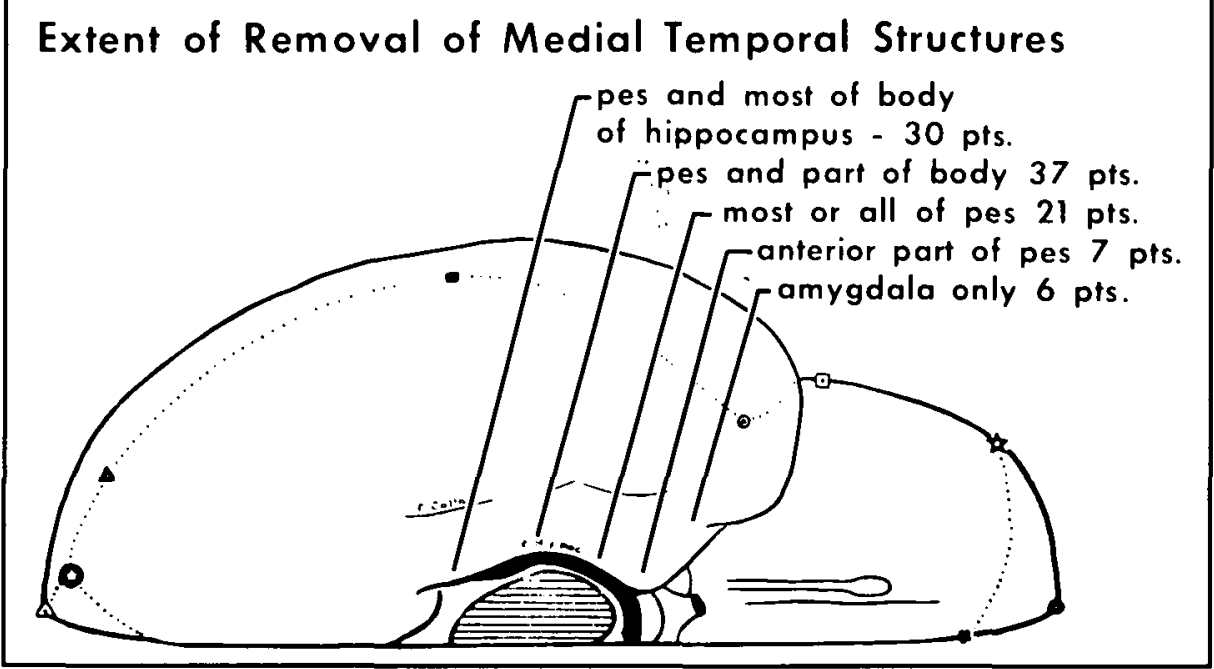

Figure 1 .

\section{SEIZURE Results}

Thirty-nine of these 100 patients (Table 1) with follow-up durations of 2 to 24 years (median duration 12 years), became and have remained seizure free, either since discharge from the hospital ( 21 patients, follow-up category 0 ), or after having a few attacks during the early postoperative months or years (18 patients, follow-up category 1 ).

In 16 patients (follow-up category 2) there was a recurrence of 1 or more attacks after an arbitrary minimum seizure free period of 3 years, which ranged up to 20 years. Eight patients (follow-up category 3 ) have averaged no more than 2 attacks per

Table 1: Temporal Lobectomy Non-Tumoral Series. Patients with Excision of the Pes Plus Half or More of Hippocampal Body.

\begin{tabular}{|c|c|c|c|c|}
\hline $\begin{array}{c}\text { Follow-up } \\
\text { Classification }\end{array}$ & Operat & d upon 196 & -1980 & \\
\hline 0 & $\begin{array}{c}\text { Seizure free } \\
\text { since discharge }\end{array}$ & 21 pts. 7 & \multirow{3}{*}{39 pts. } & \multirow{5}{*}{$\begin{array}{c}63 \text { pts. } \\
2-24 \text { yrs. } \\
\text { follow-up } \\
\text { (median } \\
12 \text { yrs.) }\end{array}$} \\
\hline 1 & $\begin{array}{c}\text { Became seizure } \\
\text { free after some } \\
\text { early attacks }\end{array}$ & 18 pts. & & \\
\hline 2 & $\begin{array}{l}\text { Seizure free } 3 \text { or } \\
\text { nore years, then rare } \\
\text { or occasional attacks }\end{array}$ & 16 pts. & & \\
\hline 3 & $\begin{array}{l}\text { Marked reduction } \\
\text { of seizure tendency }\end{array}$ & 8 pts. & \multirow{2}{*}{24 pts. } & \\
\hline 4 & $\begin{array}{l}\text { Moderate or less } \\
\text { reduction of } \\
\text { seizure tendency }\end{array}$ & 37 pts. & & \\
\hline
\end{tabular}

Total 100 pts. year over the follow-up period. These 24 patients in follow-up categories 2 and 3 are considered to have had a marked reduction of their seizure tendencies. Thus 63 of these 100 patients have had a complete or nearly complete reduction of their seizure tendencies after temporal lobectomy including removal of most of the hippocampus.

The remaining 37 patients (follow-up category 4) have had a lesser reduction of their seizure tendencies. Although they are relative surgical failures since the operation failed to reduce their seizure tendencies to normal or near normal levels, many of them have benefitted considerably from the procedure. In about a third of these follow-up category 4 patients the postoperative seizure rate has been of the order of 1 to $10 \%$ of the preoperative rate. In another third the postoperative seizure rate has ranged from about 10 to $50 \%$ compared to the preoperative rate. The remaining third have had a lesser to no reduction. They constitute about $15 \%$ of the total follow-up group and represent the real failures.

This and the following report focus upon the results obtained in reducing the patient's seizure tendencies. Time and space constraints prevent presentation of other clinical data such as seizure patterns, EEG, radiological findings, etiology, pathology, etc., but some of the psychological data of the two groups are presented in the report by Dr. Gabriel Leonard. ${ }^{3}$

\section{REFERENCES}

1. Rasmussen T. Localizational aspects of epileptic seizure phenomena. In: Thompson RA, Green JR, eds. New Perspectives in Cerebral Localization. New York: Raven Press 1982; 177-203.

2. Feindel W, Rasmussen T. Temporal lobectomy: Review of 100 cases with no or minimal hippocampal excision (this journal supplement).

3. Leonard G. Temporal lobe surgery for epilepsy: neuropsychological variables related to seizure outcome (this journal supplement). 